\title{
DETERMINANTS OF ADR RETURNS BEFORE AND AFTER DOMESTIC STOCK SEASONED EQUITY OFFERINGS: EVIDENCE FROM ASIAN AND LATIN AMERICAN EMERGING MARKETS
}

\author{
Chien-Chiang Lee ${ }^{1}$, Mei-Ping Chen ${ }^{2}$, \\ Chun-An Li ${ }^{3}$, Chi-Hung Chang ${ }^{4}$ \\ ${ }^{1,4}$ Department of Finance, National Sun Yat-sen University, Kaohsiung, Taiwan \\ ${ }^{2}$ Department of Accounting Information, National Taichung Institute of Technology, Taiwan \\ ${ }^{3}$ Department of Finance, National Yunlin University of Science \& Technology, Taiwan, \\ College of Finance and Banking, National Kaohsiung First University \\ of Science and Technology, Taiwan \\ E-mails:1'cclee@cm.nsysu.edu.tw (corresponding author); ${ }^{2}$ meiping@ntit.edu.tw;

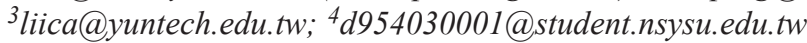

Received 01 February 2010; accepted 14 February 2011

\begin{abstract}
This paper examines the critical determinants of American depository receipt (ADR) returns before and after domestic stock seasoned equity offerings (SEOs) for Asian and Latin American emerging economies during 1990-2007, which has never been probed in related issues. We employ the Time Series Cross Section Regressions and General Method of Moments methods to document that domestic stock returns play a vital role in explaining Latin American ADR returns, while US investor sentiment is crucial in explaining Asian ADR returns. Local investor sentiment is found to be considerably important than domestic stock returns in Asian ADR returns, while Latin American local investor sentiment (US investor sentiment) is more important before (after) domestic stock SEOs. The results do not support the view that ADR-reconciled earnings per share (EPS) and stock EPS provide significant information to explain ADR returns in Latin American and Asian emerging markets both before and after SEOs. Furthermore, international market differences in a specific geography should be considered when diversifying investments and efficiency accounting communication with accounting convergence does not need to be emphasized.
\end{abstract}

Keywords: American depository receipts, seasoned equity offerings, accounting information, investor sentiment.

Reference to this paper should be made as follows: Lee, C.-C.; Chen, M.-P.; Li, C.-A.; Chang, C.-H. 2011. Determinants of ADR returns before and after domestic stock seasoned equity offerings: evidence from Asian and Latin American emerging markets, Journal of Business Economics and Management 12(2): 248-277.

JEL classification: M41, C23, R10. 


\section{Introduction}

The determinants of American depository receipt returns (hereafter ADRNs) have constituted one of the most hotly debated issues in the past two decades, yet never before has a consensus been reached as shown in Table 1 . We find that even if the same country and method are employed, the results vary. Regarding the comparison of domestic stock earnings per share (DEPS) and ADR-reconciled earnings per share (AEPS), the results of Chan and Seow (1996) and Luchs (2004), both of whom use regression models to test UK data, are conflicting. For instance, one shows that DEPS dominates the AEPS in influencing ADRNs, while the other indicates that DEPS and AEPS are equally important for UK ADRNs. The findings of previous studies that explore whether local investor sentiment (LD) has dominated US investor sentiment (USI) or vice versa are quite distinct. For example, the results of Jiang (1998) and Ely and Salehizadeh (2001), both of whom use error-correction models to examine the same countries (e.g., Germany, UK, and Japan), are also conflicting, as one shows that LD dominates USI in influencing ADRNs, while the other shows that the opposite situation holds. The differences in these findings might be due to the limitations of the specific information transmitted or the incompleteness of the variables considered.

The purpose of this paper is to expansively investigate and compare the changes in the influence of ADRN determinants for Latin American and Asian emerging markets by controlling domestic stock seasoned equity offering (SEO) events. The role of ADRs in the development of emerging markets brings advantages of liquidity, transparency, and ease of trade that characterize US markets. Firms issuing ADRs are required to file their domestic GAAP financial statements and reconcile their US GAAP accounting procedures with the SEC, thus providing investors with two sets of accounting information. However, the informativeness of the two sets of accounting information is subject to controversy.

This study comprehensively includes two accounting variables (DEPS and AEPS), two investor sentiment variables (proxy by market indices LD and USI), and domestic stock returns (SRs), as well as compares the variable impact changes on ADRNs before and after domestic stock SEOs. If the ADRNs do not fluctuate as do the SR, then there is a question regarding the causes of ADR deviation in response to SRs, LD, and/or USI, DEPS, and/or AEPS. Time Series Cross Section Regression (TSCSREG) is applied in comparing the significance among variables. Evidence of the importance among variables may have a significant bearing upon accounting harmonization and diversify investment. If DEPS contains more information than AEPS, then it signifies that earnings based on foreign GAAP may convey information that may be lost in reconciliation with US GAAP financial statements (Chan, Seow 1996). However, if DEPS and AEPS both contain sparse information regarding ADRNs, then the arguments for accounting harmonization may focus on firms' cost reduction and not on the asymmetry reduction arguments (Kirch 2007). An understanding of an ADR's role in diversification, its interrelationships with the market of origin, and its pricing factors certainly benefit many players in the ADR market (Jiang 1998). 
C.-C. Lee et al. Determinants of ADR returns before and after domestic stock seasoned equity offerings ...

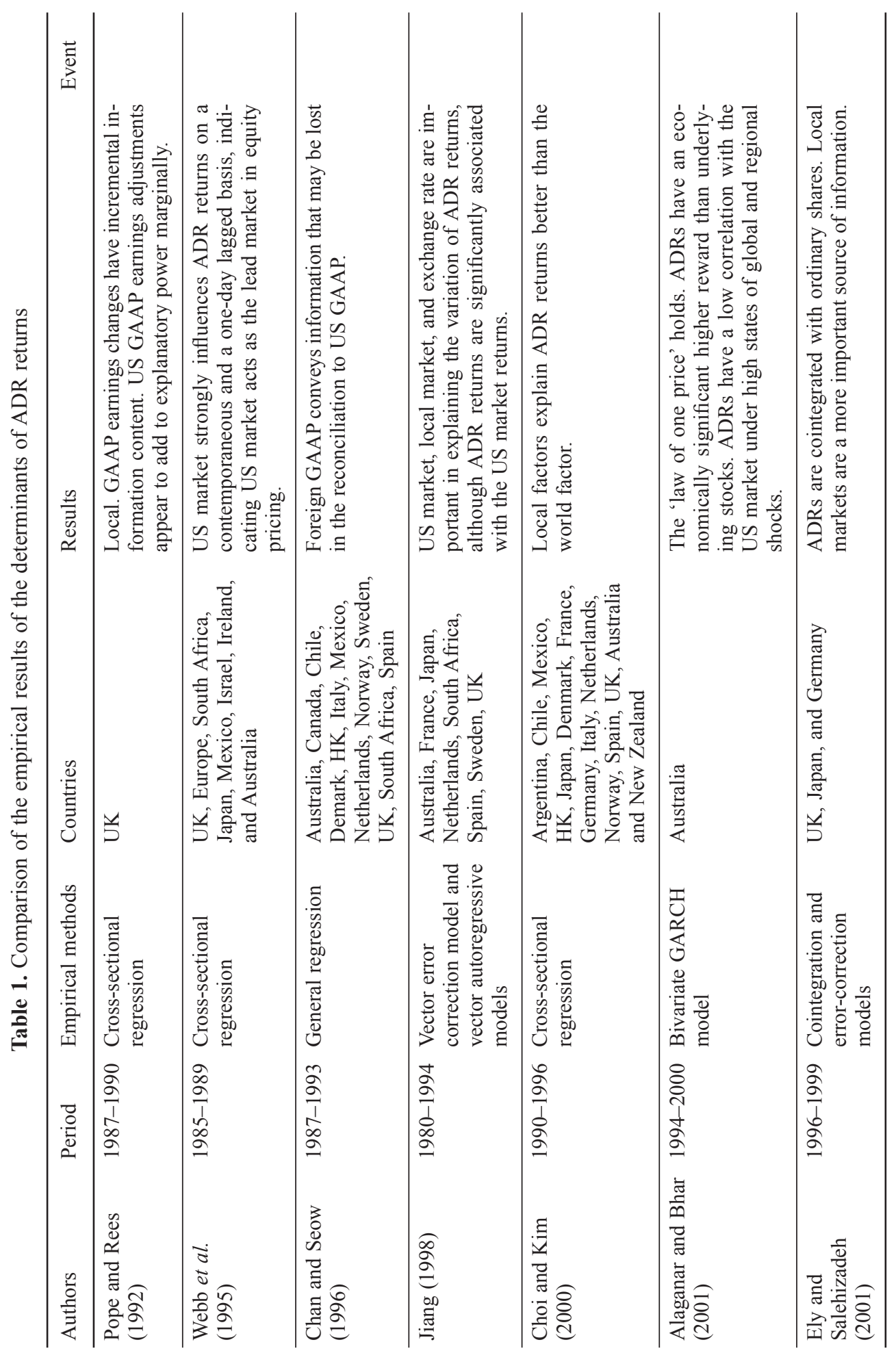


Journal of Business Economics and Management, 2011, 12(2): 248-277

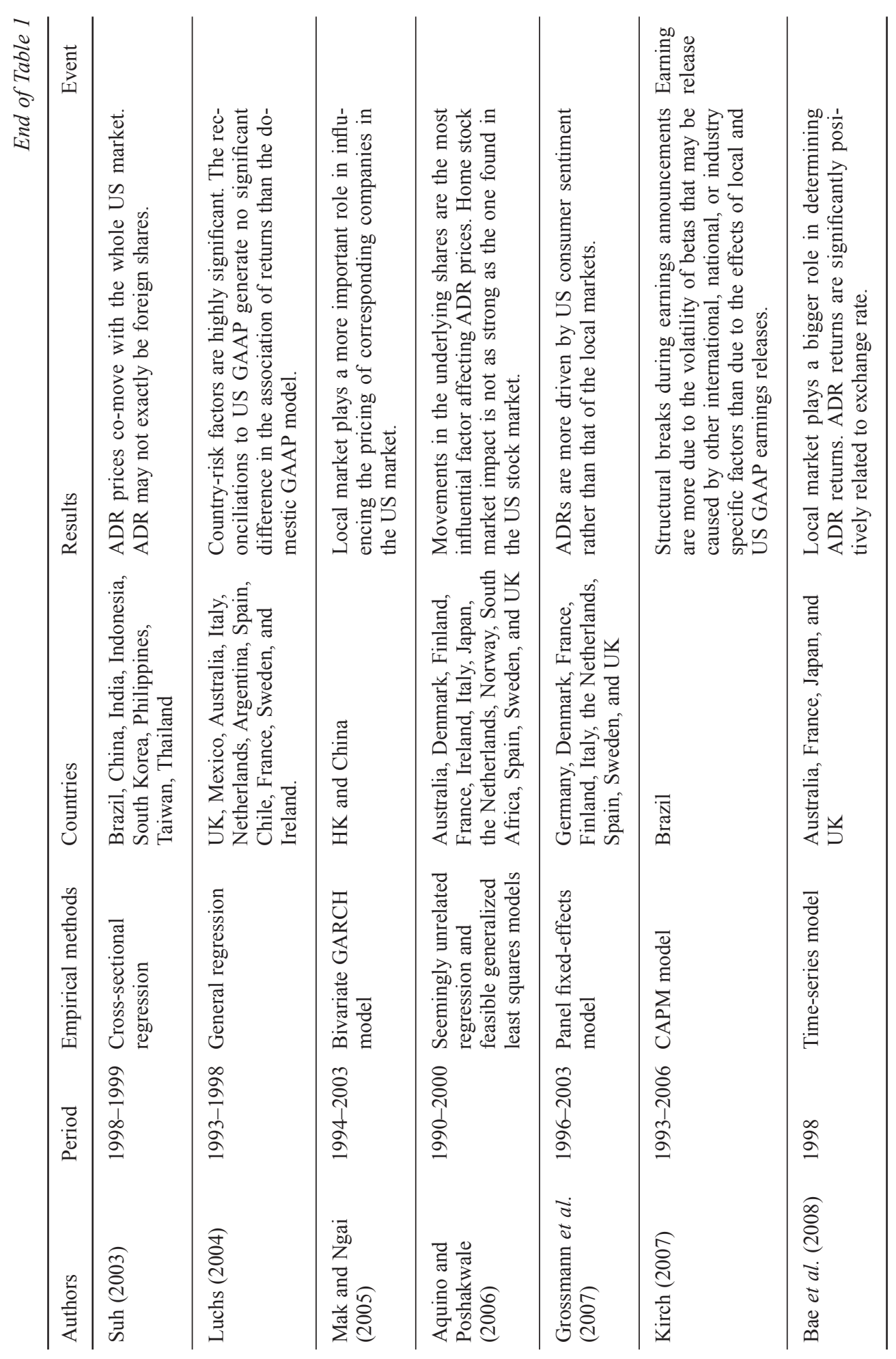


Two streams of earlier research are related to this paper. One has to do with a comparative study of ADR-related accounting variables, and the other with a comparative study of SRs, LD, and USI. Using data from the UK for 1987-1990, Pope and Rees (1992) found DEPS dominates AEPS in explaining ADRNs, indicating that the market exhibits a limited response to changes in accounting information. Empirical studies were later extended to cover other countries (Kirch 2007; Luchs 2004). However, the findings have been empirically inconclusive. Luchs (2004), for example, held the view that DEPS and AEPS provide the same level of explanatory power in regard to ADRNs. Furthermore, Kirch (2007) claimed that there were no surprises related to ADRNs during releases of both DEPS and AEPS.

As for one of the leading studies on a comparison of the influence of SRs, LD, and USI, Webb et al. (1995) found a significant relationship between ADRs and US market returns, thus signifying the leading role played by USI in relation to ADRNs. Jiang (1998) extended the analysis to apply the VAR and GARCH models that took the exchange rate into consideration and came up with opposite findings. Later results of related studies were found to be fruitful (Alaganar, Bhar 2001; Choi, Kim 2000; Ely, Salehizadeh 2001), although the empirical findings vis-à-vis such relationships were found to be mixed if not downright contradictory. Most of the findings examined the related ADR issue, either without specific events (Choi, Kim 2000; Kim et al. 2000; Patro 2000), or with selected events, such as the US market's reaction to ADR initial public offerings (IPOs) (Foerster, Karolyi 2000; Miller 1999; Sundaram, Logue 1996), the domestic stock reaction to ADR IPOs (Alexander et al. 1988; Foerster, Karolyi 1999), financial crises (Wang 2003), and profit warnings regarding the underlying stock (Jackson, Madura 2003). However, studies related to financial crises and profit warnings are rare. Furthermore, for ordinary specific event settings based on a discussion of domestic stocks, none of the studies include both accounting and market variables at the same time.

This study is related to, but distinct from, the extensive and growing literature on crosslisting. We probe into more generalized events to understand the intrinsic nature of ADRNs. To date and to the best of our knowledge, no previous study has explained the influence of changes in accounting information and investor sentiment on ADRNs arising from the issuance of SEOs in the home country. Choi and Kim (2000) examined the determinants of ADRNs and mentioned that developed and emerging markets have divergent findings. While Latin American and Asian emerging markets have extensive experience at launching their own ADR programs during the 1990s in terms of pace, breadth, and trading activity (Karolyi 2004), the differences between emerging markets are still open to question.

Level II and III ADR-listed firms must provide financial statements with limited reconciliations moving from local GAAP to US GAAP. This study examines whether the reconciled financial information fully communicates the intrinsic value of the ADRs, and if not what factors are mostly significant in explaining ADRN changes. Barberis et al. (2005, hereafter BSW) classified two distinctive views regarding the co-movement of equity prices: one adopts a traditional or fundamental-based approach based on friction- 
less economies with fully rational investors, while the other utilizes a behavioral (trading or investor sentiment-based) approach, namely, the market friction approach. BSW (2005) proposed that the behavioral approach is superior to the traditional approach. According to the findings of BSW (2005), investor sentiment rather than fundamental information is a factor in explaining ADRNs. If country-specific market sentiment is crucial, then ADR price movements can be expected to be affected primarily by local and/or US market sentiment, rather than by firm stock price and accounting information. Suh (2003) and Arquette et al. (2008) indicated that market-wide sentiment significantly affects ADRNs.

This investigation aims to contribute to the literature in four ways. First, the mixed findings of prior studies may be due to the variety of information transmitted from the local market, the US market, or domestic firms. However, few studies have set event limitations. We analyze the related variables' influence changes on ADRNs both before and after home stock SEOs, which are a common event, especially compared to infrequent financial crises and profit warnings. ADRN determinants can thus be further analyzed during a non-crisis period. Second, this work provides empirical evidence on the significant informativeness of SR, fundamental-based (DEPS and AEPS) and sentiment-based information in explaining ADRNs. Third, prior studies point to the distinct market factors that influence ADRNs between developed and emerging markets. To our knowledge, none of the studies compare the differences among emerging markets in different regions. Finally, most previous studies use time series or cross-sectional regressions. Without controlling the time effects and firm effects, a divergence of findings occurs. This study employs panel data to control for unobservable heterogeneity and eliminates the risk of obtaining biased results due to this heterogeneity (Moulton 1986). Time Series Cross Section Regression (TSCSREG) is employed to compare the importance of the variables, while Panel system General Method of Moments (GMM) models are applied to compensate for the greater accuracy ${ }^{1}$.

The remainder of this paper is organized as follows. Section 2 reviews the related literature. Section 3 describes the data. Section 4 explains the model and methodology. Section 5 discusses the empirical results, and Section 6 concludes the paper.

\section{Literature Review}

\subsection{Latin American and Asian ADRs in US Markets}

In early 1997, as emerging markets boomed, most Asian and Latin American economies looked strong and investors had a strong appetite for Argentine, Brazilian, and Indonesian securities. Asian and Latin American emerging markets seemed also not to experience any major meltdown in 2005 (MacDonald 2005). During the period from 2003 to 2005, Latin America exhibited the best DR performance, as measured by the ADR index

\footnotetext{
${ }^{1}$ Kennedy (2003) indicates that both the fixed effects and the random effects estimators are biased when a lagged dependent variable is used as an explanatory variable, suggesting the use of panel GMM or instrumental variables methods.
} 
of the Bank of New York. The good performance of Latin American equity markets was driven by factors including a healthy demand from US and other international investors willing to take risks in the area, because of lukewarm returns from US stock markets ${ }^{2}$. In addition, Bailey and Stulz (1990) demonstrated the major benefits from diversification into Asia-Pacific equities. During 2005, 68 Asian issuers from six countries and 23 sectors raised over 17.4 \$ billion from DRs, an increase of 164\% compared to 2004 . ADRs have thus grown rapidly in numerous emerging markets in Latin America and Asia during the past decade. Surely investors want to know what drives ADRNs.

\subsection{The Effect from Seasoned Equity Offerings}

SEOs occur when a listed firm issues additional shares. Smith (1977) was the first to document significant under-pricing of SEOs. Montier (2002) later stated that insiders realize the stock is overpriced and thus send a signal via a SEO, forcing the market to correct its misperceptions and creating negative announcement returns. Most relevant studies depict the SEO announcement effect as approximately minus 3\% in US markets (Mola, Loughran 2004; Foerster, Karolyi 2000).

On the other hand, SEO studies yield diverse findings regarding SEO underpricing. Spiess and Affleck-Graves (1995), along with Denis and Sarin (2001), documented abnormal stock price reactions from post-SEO earning announcements as reliably negative only for the smallest quartile of equity issuers. Lee (1997) and Gombola et al. $(1997,1999)$ demonstrated that mature firms do not share the same negative experience. Nevertheless, it remains unclear whether listed firms from emerging markets that have issued ADRs also exhibit SEO under-pricing. Jayakumar (2002) stated that cross-listing provides a credible commitment to greater firm information disclosure, less information asymmetry, increased transparency, and enhanced value via pure cash flow effects by cutting agency costs. With more analysts following ADR-listed firms, considerable firm information is publicly available (Ejara, Ghosh 2004). Based on the above findings, we estimate that ADRNs react negatively after domestic stock SEOs.

\subsection{Co-movement between ADRNs and SRs}

BSW (2005) classified co-movement theories into two groups. One contains the traditional or fundamentals-based approach of frictionless economies involving fully rational investors, while the other comprises behavioral (investor sentiment-based) or market friction approaches. Their findings support the latter approach. Moreover, Coakley and Kougoulis (2004) explained that the fundamentals-based approach means that comovement in fundamental value is instantly mirrored by a return co-movement - that is, price equals fundamental value. Recent studies have indicated that the co-movement of securities prices significantly exceeds their common fundamentals, casting doubt on the orthodox views of the rational pricing model.

Several related studies mention that SRs affect ADRNs. Choi and Kim (2000) showed that ADRs and underlying stocks have closely correlated returns. Alaganar and Bhar

\footnotetext{
${ }^{2}$ Depository Receipt Markets 2005 Yearbook, please see www.adrbny.com/files/ms7752.pdf.
} 
(2001), Kato et al. (1991), Maldonado and Saunders (1983), Park and Tavakkol (1994), and Wahab et al. (1992) confirmed that ADR markets are priced efficiently, and that a 'law of one price' exists, with dominant information flow from underlying stocks to ADRs. Foerster and Karolyi (1999) found that ADRs follow on the heels of abnormally positive stock price performance in the year leading up to the listing. Similar evidence exists for Canadian listings and ADRs, as reported by Alexander et al. (1988). Few investigations have explored ADRNs with SR co-movement in common specific events other than ADR IPOs, financial crises, and profit warnings, i.e., SEOs. This work, distinct from the previous literature, explores home stock SEO information transmission to ADRs. Large firms, as ADR-listed firms, enjoy an information-rich environment and firm-specific information is preempted in the market. Thus, we hypothesize that SRs affect ADRNs equally, regardless of whether they are measured before and after SEOs.

\subsection{Investor Sentiment Influences ADRNs}

Behavioral finance studies routinely challenge the conventional argument that market participants behave rationally. Studies on investor sentiment are therefore crucial: they educate us regarding biases in investor forecasts on the stock market and also in order to gain additional returns. Then again, sentiment indicators are widely recognized as a reliable contrarian indicator of market movement (Siegel 1998). The behavioral finance theory of DeLong et al. (1990, hereafter DSSW) predicts noise trader sentiment that persists in financial markets and changes in investor sentiment are obviously difficult to forecast, otherwise they would be arbitraged away. Black (1986) and DSSW (1990) documented how noise traders acting together in response to non-fundamental signals cause asset prices to deviate from intrinsic values. A prime example of twin security puzzles involving Royal Dutch and Shell is mentioned by Froot and Dabora (1999). They showed Royal Dutch and Shell as being claims on the same cash flow. In an efficient market, Royal Dutch and Shell should trade at a constant ratio, but Royal Dutch is more sensitive to moves in the US market, while Shell is more sensitive to the UK market. Specifically, twin securities are correlated with their present market, despite this behavior being unrelated to changes in fundamentals.

If the USI exerts less of an impact on ADRNs than LD, then ADRs can be employed to signal global risk diversification; if USI exerts greater influences than LD, then movements in USI will dominate LD. Alaganar and Bhar (2001) and Kim et al. (2000) viewed ADRNs as being more strongly affected by SRs than by US market movements. Jiang (1998) confirmed a relationship between ADR and home market returns. Conversely, if investor-based specific market sentiment is critical to equity pricing, then ADRNs can be expected to be influenced by USI, with ADRs being traded by US traders (Suh 2003). Based on the announcements of SEOs regarding listed firms, ADRNs can be influenced by LD, yet studies demonstrate that listed firms in emerging markets are strongly influenced by global leading US capital markets (Ehrmann, Fratzscher 2005). The correlation between ADRNs and US (local) market indices indicates that US (local) market sentiment influences ADRN movements. Officer and Hoffmeister (1987) found little covariance between ADR prices and the prices of the underlying securities. 
Moreover, Webb et al. (1995) used information on ADRs and USI to confirm US dominance in lead/lag relationships among equity markets. Since the US is a global leader among capital markets, USI may exert greater influences on ADRs than LD. Therefore, we examine and compare the change in the influence of LD and USI on ADRNs before and after domestic firm SEOs.

\subsection{ADR Accounting Communication and Accounting Convergence}

ADRs issued by US agencies for non-US firms cross-listed on US markets are negotiable securities issued by a US commercial bank backed by the equity shares of non-US parent firms. Four levels of ADR programs exist: Levels I, II, III, and $144 \mathrm{a}^{3}$. Levels II and III comply with all SEC registration and reporting requirements, including ADR program registration on SEC Form F-6, as well as annual reporting on Form F-20, with either partial or full reconciliation of financial statements to increase investor confidence by providing financial statement information. Registration allows issuers to list ADRs on one US stock exchange (NYSE, AMEX, and NASDAQ) provided the listing requirements are met (Callaghan et al. 1999).

Previous research on international financial reports identified notable qualitative differences among nations in their financial reporting standards (Meek, Saudagaran 1990). Baumol and Malkiel (1993) argued that further disclosure of ADR issuing requirements in accordance with US GAAP provides scant benefit to investors, contending that information on foreign GAAP numbers may be untranslatable, because of differences in tax laws, corporate governance, inter-corporate ownership of securities, and other institutional features. Level II and III reconciliations may mislead US investors into making unwarranted inferences. Amir et al. (1993) as well as Meek (1983) also presented evidence that $20-\mathrm{F}$ announcement dates contain no incremental information. Bradshaw et al. (2004) identified several reasons why 20-F may not provide an effective substitute for accounting choice in primary financial statements. Chan and Seow (1996) demonstrated a closer association with 12-month returns for domestic GAAP income than for returns reconciled to US GAAP income. This study expects that if the reconciled items from moving local GAAP to US GAAP in ADR financial statements can effectively eliminate information asymmetries between local and US investors, then reconciliation for ADR listing firms can provide an intermediate by means of attracting US investment and can effectively transfer local information to its ADR price. Conversely, if reconciliation items cannot effectively eliminate such asymmetry between investors in the domestic country and the US, ADR price movements are caused by other factors. The International Accounting Standards Committee strives to achieve a global set of accounting principles, also known as the International Financial Reporting Standards

\footnotetext{
${ }^{3}$ Level I ADRs are traded on the US OTC market and do not needs to be reported based on US GAAP, nor do they require full SEC disclosure. Rule 144a issues are traded only among qualified institutional buyers on the PORTAL system. A key difference between Level II and III ADRs is that SEC regulations do not permit a public offering of ADRs under Level II programs, while the Level III program enables the issuer to raise capital via a public offering of ADRs in the US (Callaghan et al. 1999).
} 
(IFRS). Intuitive logic regarding convergence is that a thriving global capital market requires greater investor understanding and confidence. Embracing common high-quality accounting standards can reduce costs not only for issuers, but also reduce the costs to firm personnel involved in complying with the requirements of multiple jurisdictions emanating from cross-listing. Moreover, such convergence reduces the costs of preparers and auditors in juggling the application of several sets of national standards within the same consolidated group. Convergence helps optimize the resources dedicated to setting standards and enables more resources to be devoted to establishing a unified accounting model for a particular topic rather than those resources being spread out in the pursuit of separate national accounting standards for the same topic. IFRS can hopefully expedite firms in listing across borders, integrate national capital markets, and increase competition in those markets ${ }^{4}$. If changes in ADRNs cannot be attributed to earnings reconciled from local stock and parent firm earnings, then based on comparability and consistency, global accounting convergence is required.

\section{Data}

Firms must satisfy the following criteria for inclusion in our study samples: First, ADRs from 13 emerging markets in Latin America (Brazil, Chile, Colombia, Mexico, Peru) and Asia (China, India, Indonesia, South Korea, Malaysia, Philippines, Taiwan, and Thailand) included in the MSCI Emerging Markets Free Index (EMF) as of 2010 and with effective listings following 1990/12/31 are used for investigation ${ }^{5}$. ADRs used in this investigation must belong to Level II and III programs ${ }^{6}$ - namely, larger, highprofile ADRs listed on major US exchanges, rather than smaller ADRs listed and traded in OTC and private-placement issues. Data for Level II and III ADRs are listed on the website of the Bank of New York.

Second, a sample firm should conduct an SEO at least one year following the effective issue dates of the underlying ADRs. SEO samples were gathered from the Global New Issues database of Securities Data Company (SDC) during 1990 to 2007. According to D'Mello et al. (2003), SDC filing dates serve as the announcement dates. Since this work examines the performance of equity issuers over one year intervals pre- and post-SEO, it is a requirement that firms have not conducted an equity offering over one preceding year. In other words, upon a firm's completion of a SEO, it cannot re-enter the sample for at least one year following the SEO date. Third, this investigation gathers ADRNs and domestic listed firm earnings data from Compustat. SR, USI, and LD, as well as exchange rate (EXR) data, are obtained from Datastream. After eliminating firms for which relative data are missing, the final sample contains 31 SEO events from

\footnotetext{
${ }^{4}$ Speech by SEC Deputy Chief Accountant, Erardt (2005), entitled "Remarks before convergence: the future of international financial reporting".

${ }^{5}$ Parent stock price and local price indexes for Asian countries lag US markets by one day owing to time differences. Latin American and US data are from roughly the same time zone and thus same date data are used.

${ }^{6}$ Kang (2003) used Level II and III programs as a sample, but did not separate them for analysis.
} 
23 firms of six countries, including Latin America (Brazil, Chile, Mexico) and Asia (Indonesia, South Korea, Taiwan)

The market index is one of the most popular indicators of daily investor sentiment (Minana 2003; Wang 2003). Minana (2003) and Wang (2003) employed the local index and S\&P 500 as proxies for local and US market sentiment. Hence, this study takes the S\&P 500 and local composite price index as a proxy for USI and LD. Table 2 indicates that the largest contingent comprises seven Chilean firms, followed by six Brazilian firms. Other countries are ordinary listings. Among the sample firms, six are in Asia while 17 are in Latin America ${ }^{7}$. Table 3 lists yearly distributions for SEOs in this sample. Table 4 provides summary statistics of the sample organized according to listing year and listing exchange. Most listings occur on the NYSE, with only three firms listing on the NASDAQ. Manufacturing and telecommunications dominate the industry distribution listed in Table 5.

Table 2. Sample of emerging market stock SEOs issued over 1990-2007

\begin{tabular}{lllll}
\hline No. of firms & Observation & Filing Date & Issuer & Nation \\
\hline 1 & 1 & $2003 / 04 / 02$ & Cia Siderurgica Nacional & Brazil \\
\hline 2 & 2 & $2001 / 05 / 09$ & EMBRAER & Brazil \\
\hline 3 & 3 & $2007 / 01 / 23$ & EMBRAER & Brazil \\
\hline 4 & 4 & $2002 / 08 / 07$ & NET Servicos & Brazil \\
\hline 5 & 5 & $2001 / 06 / 28$ & Petroleo Brasileiro SA & Brazil \\
\hline 6 & 6 & $2004 / 09 / 28$ & Sabesp & Brazil \\
\hline 7 & 7 & $2003 / 08 / 08$ & Uniao de Bancos & Brazil \\
\hline 8 & 8 & $1999 / 10 / 14$ & AFP Provida SA & Chile \\
\hline 9 & 9 & $1998 / 05 / 29$ & Cia de Telecom. & Chile \\
\hline & 10 & $1998 / 08 / 07$ & Endesa & Chile \\
\hline 10 & 11 & $1999 / 09 / 23$ & Endesa & Chile \\
\hline 12 & $1998 / 08 / 10$ & Enersis SA & Chile \\
\hline 11 & 13 & $1999 / 08 / 26$ & Enersis SA & Chile \\
\hline 12 & 14 & $2003 / 03 / 31$ & Enersis SA & Chile \\
\hline 13 & 15 & $2003 / 06 / 06$ & Madeco SA & Chile \\
\hline 14 & 16 & $2007 / 05 / 10$ & Lan Airlines SA & Chile \\
\hline & 19 & $1998 / 06 / 02$ & SQM & Chile \\
\hline
\end{tabular}

\footnotetext{
${ }^{7}$ Appendix presents more detailed information regarding the sample firms in our examinations.
} 
End of Table 2

\begin{tabular}{lllll}
\hline No. of firms & Observation & Filing Date & Issuer & Nation \\
\hline 15 & 20 & $2005 / 09 / 28$ & CEMEX SA DE CV & Mexico \\
\hline 16 & 21 & $2005 / 12 / 19$ & Desarrolladora Homex & Mexico \\
\hline & 22 & $2003 / 12 / 18$ & Empresas ICA Sociedad & Mexico \\
\hline 17 & 23 & $2005 / 08 / 09$ & Empresas ICA Sociedad & Mexico \\
\hline 18 & 24 & $2007 / 09 / 01$ & Empresas ICA Sociedad & Mexico \\
\hline 19 & 25 & $2006 / 10 / 26$ & Grupo Simec SAB de CV & Mexico \\
\hline 20 & 27 & $2002 / 05 / 16$ & Indosat & Indonesia \\
\hline 21 & 28 & $2002 / 07 / 16$ & Telkom & Indonesia \\
\hline 22 & 29 & $2002 / 11 / 04$ & Hanaro Telecom Inc & South Korea \\
\hline 23 & 30 & $2002 / 05 / 07$ & KT Corp & South Korea \\
\hline
\end{tabular}

Note: According to the 2010 MSCI Emerging Markets Index, 13 of 21 emerging market country indices from Asia and Latin America included in this study are: Brazil, Chile, China, Colombia, India, Indonesia, South Korea, Malaysia, Mexico, Peru, Philippines, Taiwan, and Thailand. After matching ADRs with effective date before 2006 from Bank of New York ADR database, 1990-2007 SEO filling data from SDC, and accounting data before 2008 from Computstat, 31 observations from 23 firms are found and used to conduct the empirical analysis. Finally, owing to no matching data from China, Colombia, India, Malaysia, Peru, Philippines, and Thailand, the observations are from six countries: Brazil, Chile, Indonesia, South Korea, Mexico, and Taiwan.

Table 3. Yearly distributions of international equity issues

\begin{tabular}{llll}
\hline Year of SEO & No. & Year of SEO & No. \\
\hline 1998 & 4 & 2003 & 6 \\
\hline 1999 & 5 & 2004 & 1 \\
\hline 2000 & 1 & 2005 & 3 \\
\hline 2001 & 2 & 2006 & 1 \\
\hline 2002 & 5 & 2007 & 3 \\
\hline
\end{tabular}

Table 4. Descriptive statistics for listed firms on ADRs

\begin{tabular}{llll}
\hline Listing Years & \multicolumn{3}{c}{ Listing Exchange } \\
\hline $1992-1995$ & 9 & NYSE & 20 \\
\hline $1996-1999$ & 6 & NASDAQ & 3 \\
\hline $2000-2004$ & 8 & & \\
\hline
\end{tabular}


C.-C. Lee et al. Determinants of ADR returns before and after domestic stock seasoned equity offerings ...

Table 5. Industry distribution of ADRs

\begin{tabular}{ll}
\hline Industry & Number of observations \\
\hline Banking and general finance & 2 \\
\hline Telecommunication and telephone & 6 \\
\hline Natural resources & 2 \\
\hline Radio/TV/Media & 1 \\
\hline Electricity and technology & 3 \\
\hline Construction & 2 \\
\hline Manufacturing & 6 \\
\hline Transportation & 1 \\
\hline Total & 23 \\
\hline
\end{tabular}

Table 6 lists the descriptive statistics regarding SRs, ADRNs, LD, USI, DEPS, and AEPS for Latin American and Asian one-year pre- and post-SEO interval daily data. Panel A tabulates the related Latin American and Panel B Asian data. This investigation applies the S\&P 500 and local composite price index as proxies for USI and LD. By dividing SR by the same date EXR, SR is translated into US dollars to eliminate the confounding effect of EXR. Annual DEPS in US dollars for firm $i$ during SEO in year $t$ is taken as the figure for underlying stock; annual AEPS for firm $i$ during the domestic stock SEO year represents ADR EPS. Table 7 shows the correlation matrix of variables. Panel A tabulates the Latin American data while Panel B tabulates the Asian data.

Table 6. Descriptive statistics

\begin{tabular}{|c|c|c|c|c|c|c|}
\hline Variable & $\Delta \mathrm{SR} \%$ & $\triangle \mathrm{ADRN} \%$ & $\Delta \mathrm{LD} \%$ & $\Delta \mathrm{US} \%$ & DEPS & AEPS \\
\hline \multicolumn{7}{|c|}{ Panel A. Latin America Pre-SEO } \\
\hline Mean & 0.0016 & 0.0039 & -0.0002 & -0.0002 & 0.7343 & 0.0006 \\
\hline Median & 0.0000 & 0.0000 & 0.0000 & -0.0002 & 0.2570 & 1.2900 \\
\hline Maximum & 3.5164 & 9.2041 & 0.2157 & 0.0737 & 3.8400 & 4.9200 \\
\hline Minimum & -0.2331 & -0.8925 & -0.0707 & -0.0542 & -1.3240 & -14.2000 \\
\hline Std. Dev. & 0.0526 & 0.1673 & 0.0128 & 0.0117 & 1.2671 & 4.4450 \\
\hline Skewness & 46.1654 & 51.3769 & 1.0115 & 0.0731 & 0.9920 & -2.4929 \\
\hline Kurtosis & 3071.275 & 2828.138 & 19.2135 & 6.2646 & 3.0800 & 8.4401 \\
\hline Observations & 6475 & 6475 & 6475 & 6475 & 6475 & 6475 \\
\hline
\end{tabular}


End of Table 6

\begin{tabular}{|c|c|c|c|c|c|c|}
\hline Variable & $\Delta \mathrm{SR} \%$ & $\triangle \mathrm{ADRN} \%$ & $\Delta \mathrm{LD} \%$ & $\Delta \mathrm{US} \%$ & DEPS & AEPS \\
\hline \multicolumn{7}{|c|}{ Latin America Post-SEO } \\
\hline Mean & 0.0009 & 0.0011 & 0.0008 & 0.0004 & 0.6726 & 0.6299 \\
\hline Median & 0.0001 & 0.0000 & 0.0003 & 0.0001 & 0.2570 & 1.3900 \\
\hline Maximum & 0.2934 & 0.8333 & 0.0682 & 0.0509 & 4.7700 & 4.9200 \\
\hline Minimum & -0.1737 & -0.4273 & -0.0918 & -0.0680 & -2.0700 & -14.2000 \\
\hline Std. Dev. & 0.0262 & 0.0358 & 0.0133 & 0.0111 & 1.4833 & 3.4116 \\
\hline Skewness & 0.5244 & 2.4065 & -0.1119 & -0.0734 & 1.0500 & -3.1610 \\
\hline Kurtosis & 13.2336 & 82.0380 & 6.2316 & 5.7238 & 4.1274 & 14.4643 \\
\hline Observations & 6375 & 6375 & 6375 & 6375 & 6375 & 6375 \\
\hline \multicolumn{7}{|c|}{ Panel B. Asia Pre-SEO } \\
\hline Mean & -0.0005 & -0.0010 & -0.0015 & 0.0001 & 0.6710 & 0.5862 \\
\hline Median & 0.0000 & 0.0000 & -0.0005 & 0.0000 & 0.1815 & 0.7850 \\
\hline Maximum & 0.1791 & 0.2575 & 0.1248 & 0.0885 & 2.7610 & 1.4500 \\
\hline Minimum & -0.1789 & -0.1557 & -0.1107 & -0.1138 & -0.6650 & -0.7100 \\
\hline Std. Dev. & 0.0340 & 0.0324 & 0.0219 & 0.0177 & 1.1543 & 0.8457 \\
\hline Skewness & 0.0486 & 0.4130 & -0.1832 & -0.3747 & 0.7460 & -0.2970 \\
\hline Kurtosis & 6.2961 & 8.8902 & 6.0454 & 7.2302 & 2.1970 & 1.4335 \\
\hline Observations & 1554 & 1554 & 1554 & 1554 & 1554 & 1554 \\
\hline \multicolumn{7}{|l|}{ Asia Post-SEO } \\
\hline Mean & 0.0013 & 0.0012 & -0.0000 & 0.0003 & 0.6710 & 0.5862 \\
\hline Median & 0.0000 & 0.0000 & 0.0000 & 0.0000 & 0.1815 & 0.7850 \\
\hline Maximum & 0.1617 & 0.2439 & 0.0986 & 0.1322 & 2.7610 & 1.4500 \\
\hline Minimum & -0.2225 & -0.1983 & -0.1194 & -0.1202 & -0.6650 & -0.7100 \\
\hline Std. Dev. & 0.0371 & 0.0346 & 0.0213 & 0.0206 & 1.1543 & 0.8457 \\
\hline Skewness & 0.1966 & 0.8430 & -0.2836 & 0.4893 & 0.7460 & -0.2970 \\
\hline Kurtosis & 6.4055 & 10.8118 & 5.7536 & 7.4122 & 2.1970 & 1.4335 \\
\hline Observations & 1554 & 1554 & 1554 & 1554 & 1554 & 1554 \\
\hline
\end{tabular}

Note: SR figures are expressed in US dollars. Samples of 23 firms are screened from Datastream for LD, USI, SR, and ADRN. LD and USI, and SR and ADRN are expressed in change percentages. DEPS and AEPS are obtained from Compustat. ADRN ${ }_{i, t}$ represents the change in daily returns for ADR for firm $i$ during day $t$; $\mathrm{SR}_{i, t}$ is the change in daily returns for every stock in US dollars for firm $i$ during day $t$; $\mathrm{USI}_{t}$ denotes the daily change in the $\mathrm{S} \& \mathrm{P} 500$ during day $t ; \mathrm{LD}_{i, t}$ is the daily change in the domestic market index for firm $i$ during day $t$ DEPS $_{i, t}$ is the annual domestic stock EPS for firm $i$ during SEO year $t, \mathrm{AEPS}_{i, t}$ is annual ADR EPS for firm $i$ during SEO $t$ year. 
Table 7 reveals that, first, Latin American and Asian ADRNs are strongly positively correlated with LD for the entire period, meaning that LD is important in explaining Latin American and Asian ADRNs. Second, for the Latin American sample the only difference in the results for the two sub-periods is that AEPS is strongly and negatively correlated with ADRNs pre-SEO, while USI significantly impacts ADRNs, meaning the change in AEPS decreases with increasing ADRNs. Third, USI is positively correlated with Asian ADRNs for the entire period.

Table 7. Correlation coefficients

\begin{tabular}{|c|c|c|c|c|c|c|}
\hline & SR & ADRN & LD & USI & DEPS & AEPS \\
\hline \multicolumn{7}{|c|}{ Panel A. Latin-America Pre-SEO } \\
\hline SR & 1.00 & & & & & \\
\hline ADRN & $0.04 * *$ & 1.00 & & & & \\
\hline LD & $0.42 * *$ & $0.04 * *$ & 1.00 & & & \\
\hline USI & $0.15 * *$ & 0.02 & $0.43 * *$ & 1.00 & & \\
\hline DEPS & $-0.03 *$ & -0.02 & $-0.04 * *$ & -0.01 & 1.00 & \\
\hline AEPS & -0.01 & $-0.06^{* *}$ & 0.01 & -0.02 & $0.32 * *$ & 1.00 \\
\hline \multicolumn{7}{|c|}{ Latin America Post-SEO } \\
\hline SR & 1.00 & & & & & \\
\hline ADRN & $0.50 * *$ & 1.00 & & & & \\
\hline LD & $0.47 * *$ & $0.28 * *$ & 1.00 & & & \\
\hline USI & $0.26 * *$ & $0.22 *$ & $0.45 * *$ & 1.00 & & \\
\hline DEPS & 0.01 & -0.00 & 0.01 & -0.00 & 1.00 & \\
\hline AEPS & -0.01 & -0.01 & -0.00 & -0.01 & $0.32 * *$ & 1.00 \\
\hline \multicolumn{7}{|c|}{ Panel B. Asia Pre-SEO } \\
\hline SR & 1.00 & & & & & \\
\hline ADRN & $0.47 * *$ & 1.00 & & & & \\
\hline LD & $0.54 * *$ & $0.37^{* *}$ & 1.00 & & & \\
\hline USI & $-0.13^{* *}$ & $0.14 * *$ & $0.21 * *$ & 1.00 & & \\
\hline DEPS & -0.01 & 0.00 & -0.02 & 0.00 & 1.00 & \\
\hline AEPS & -0.01 & 0.00 & 0.00 & 0.03 & $0.47 * *$ & 1.00 \\
\hline \multicolumn{7}{|c|}{ Asia Post-SEO } \\
\hline SR & 1.00 & & & & & \\
\hline ADRN & $0.48^{* *}$ & 1.00 & & & & \\
\hline LD & $0.41 * *$ & $0.35 * *$ & 1.00 & & & \\
\hline USI & $-0.24 * *$ & $0.19 * *$ & $0.24 * *$ & 1.00 & & \\
\hline DEPS & 0.01 & 0.01 & -0.01 & -0.01 & 1.00 & \\
\hline AEPS & -0.02 & -0.02 & -0.01 & -0.02 & $0.47 * *$ & 1.00 \\
\hline
\end{tabular}

Note: ** $(*)$ denote significance at the $1 \%(5 \%)$ level (a two-tailed test). USI is the S\&P 500 composite stock price index. LD is the composite price index. 


\section{Model and Methodology}

\subsection{Random Effects Model}

Follow the methodology of Areal et al. (2007), this study uses panel data regression method, which takes the firm-specific and time effects to analyze the relation between ADRNs and its correlated variables. Panel data follow the same firms (countries) over time, helping to facilitate the analysis of dynamic responses and the control of unobserved heterogeneity (Arellano 2003). By combining time series of cross-section observations, panel data provide more informative data and are better suited to study the dynamic of change that simply cannot be observed in pure cross-section or pure time series data (Gujarati 2003). With the indication that the impacts on ADRN are different among SR, LD, USI, DEPS, and AEPS, additional analysis is needed to determine if indeed the differing influences are diverse between domestic stock before and after SEO. The basic structure for analyzing the panel data is given by the following equation (1):

$$
y_{i t}=\sum_{k=1}^{K} X_{i t K} \beta_{K}+u_{i t} i=1, \ldots, N ; \mathrm{t}=1, \ldots, T,
$$

where $N$ denotes the number of cross sections, $T$ represents the length of the time series for each cross section, $K$ is the number of exogenous or independent variables, and $\beta$ is the estimated coefficient of vectors across cross-sectional observations, where $i$ denotes the company and $t$ denotes time. Therefore, $y_{i t}$ is the dependent variable pooling $N$ cross-sectional observations and $T$ time-series observations, and $X_{i t K}$ are the independent variables pooling $N$ cross-sectional observations and $T$ time-series observations. Here, $u_{i t}$ is a random error term, and $u_{i t}=u_{i t}+v_{i t}$, where $v_{i t}$ denotes the remainder of the disturbance.

The two-way (time-invariant / firm-specific) effect is randomly distributed and is uncorrelated with the vector of exogenous variables. Using the Hausman (1978) test, the sample data employ random effects, rather than fix effects. The panel data have four model types: basic model, individual-effect model, fixed effects model, and randomeffects model. Both fixed-effects and random-effects models can be further divided into one-way and two-way types of models. The difference between ordinary least squares (OLS), fixed-effects model, and random-effects model is that OLS calculation can only be analyzed either through cross-sectional or time-series data at a time. Therefore, when a combination of data appears, using OLS may overlook the differences embedded in the cross-sectional data and thus generate unreliable estimate results. While the fixedeffects model and random-effects model can deal with the two data types simultaneously, given special consideration to the differences within cross-sectional data, we can eliminate discrepancies among samples. The estimation result gained will also be more efficient and consistent (Cheng et al. 2010).

\subsection{Time Series Cross Section Regression (TSCSREG) Analysis}

The TSCSREG procedure is used to compare the significance of variables. One of the main strengths of the TSCSREG design is that it allows for controlling heterogeneity bias, or the confounding effect of time-invariant variables omitted from the regression 
model (Nielsen 1999). The TSCSREG procedure involves panel datasets that comprise time series observations for each of several cross-sectional units. The performance of any estimation procedure for the model regression parameters depends on the statistical characteristics of the model's error components. The TSCSREG procedure requires that the time series for each cross section have the same number of observations and cover the same time range. The test performs $F$-tests of linear hypotheses regarding regression parameters in the preceding models. Each equation specifies a linear hypothesis to be tested. All hypotheses in one test are tested jointly. Variable names in equations must correspond to regressors in the preceding model, and each name represents the coefficient of the corresponding regressor (Santiago-Castro, Brown 2007).

Chan and Seow (1996) incorporated annual accounting earnings under US GAAP and foreign GAAP as the independent variables in order to probe the association between SR and foreign GAAP earnings versus earnings adjusted to US GAAP. We extend their models by including investor sentiment and accounting information variables. The hypotheses are tested using the following panel regression model (2):

$$
\mathrm{ADRN}_{i, t}=\beta_{0}+\beta_{1} \mathrm{SR}_{i, t}+\beta_{2} \mathrm{USI}_{t}+\beta_{3} \mathrm{LD}_{i, t}+\beta_{4} \mathrm{DEPS}_{i, t}+\beta_{5} \mathrm{AEPS}_{i, t}+\varepsilon_{i, t} .
$$

Here, the $\beta s$ are the estimated coefficients and $\varepsilon$ is the random disturbance term. Employing the balanced panel dataset, equation (2) is investigated to examine the impact change of the main variables on ADRNs.

\section{Empirical Results}

The Hausman (1978) test results provide the choice of the random effects model for all conventional significance levels in four sample groups (Latin American and Asian data pre- and post-SEO). In this study the fixed effect model is thus infeasible, because annual EPS variables exhibit minimal time variation. Consequently, this study employs a random effects model to examine the variables determining the ADRNs. The TSCSREG procedure is mainly employed to compare the significant associations of related variables with ADRNs. Tables 8 and 9 provide Latin American and Asian results of the two-way random effects models and TSCSREG, where the dependent variable is daily ADRN. While the models (Latin American and Asian pre- and post-SEO results) do not have high $F$ values and $R^{2}$, they exhibit a key variable impact on ADRNs, and the probabilities are significant at the $1 \%$ level. Furthermore, models excluding insignificant variables in Tables 8 and 9 are also examined to check the stability of results, as shown in Tables 10 and 11. Finally, this study uses the panel system GMM to perform the robustness check. Table 12 summarizes the findings.

\subsection{Latin American Results}

Table 8 presents estimation results as well as some traditional tests for Latin American markets. The Durbin-Watson statistics are near 2, implying that there is little evidence of serial correlation in our sample since the null hypothesis of no autocorrelation in the residuals would not be rejected if the DW statistic is near 2 (Brooks 2002). 


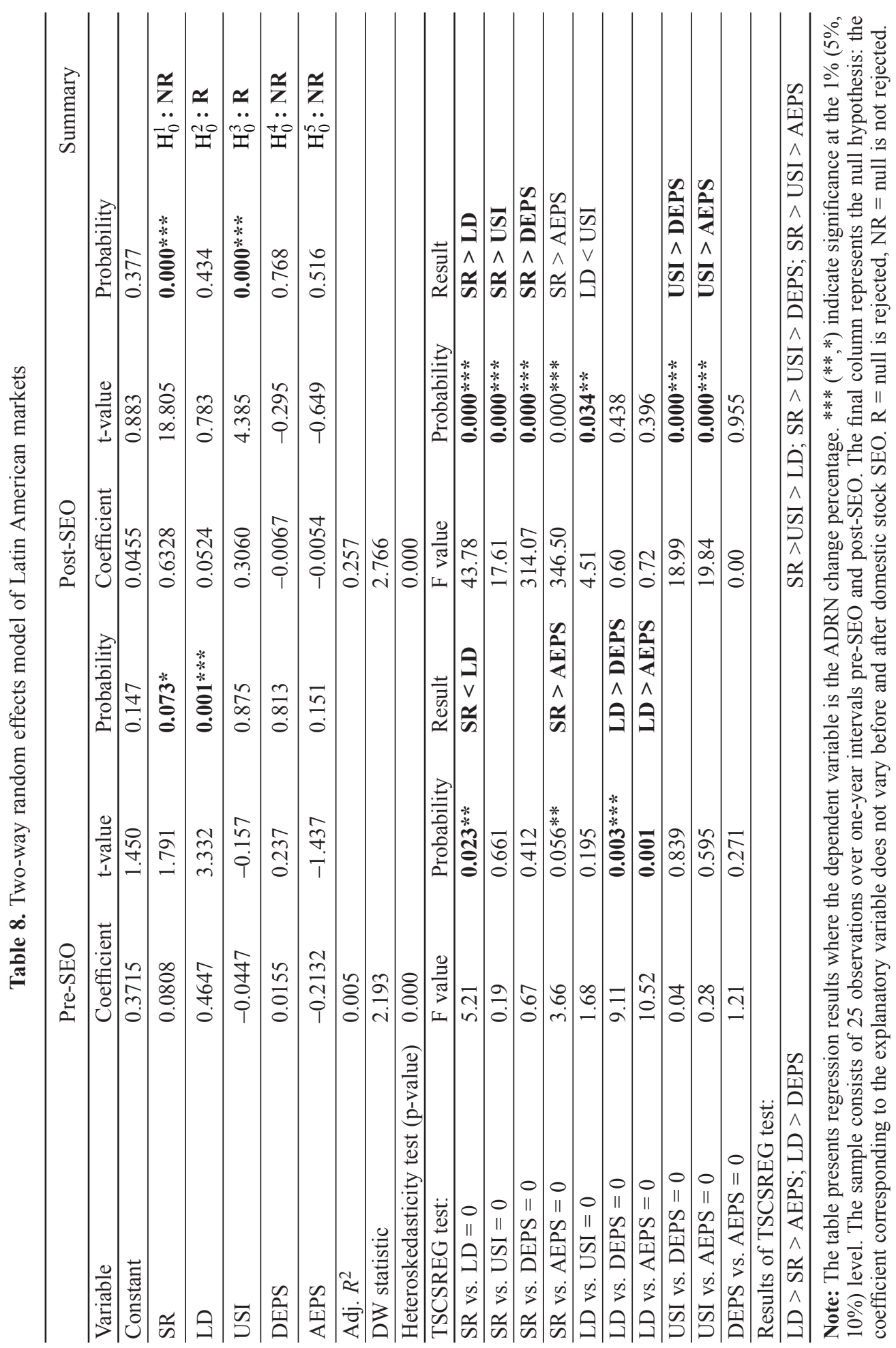


On the other hand, the data are plagued by heteroskedasticity, and thus we adopt robust estimates to correct for cross-sectional heteroskedasticity. The estimation results show that SR variables exert a significantly positive effect on ADRNs both before and after domestic stock SEOs. The null hypotheses of SRs affecting ADRNs equally for domestic stock both pre- and post-SEO cannot be rejected. In other words, SR equally and considerably affects ADRN full period returns in the Latin American sample. However, LD markedly affects Latin American ADRN pre- but not post-SEOs and USI post- but not pre-SEOs. This study rejects the hypotheses that LD and USI affect ADRNs equally pre- and post-SEO. Variables which are shown to insignificantly impact ADRN include DEPS and AEPS for the full period, implying that investors do not refer to DEPS and AEPS when investing in Latin American ADRs, either pre- or post-SEO.

Table 8 shows the TSCSREG tests to examine the relative importance of different factors on ADRNs and whether the difference between these factors is significant. The results show that SR in Latin American markets has a uniform effect on full period ADRN and that the effect is significantly lower than LD pre-SEO, but higher post-SEO. The intuition behind this observation is as follows. Firm capital will expand after SEOs, and investors will pay more attention to the issue of whether SR can remain after the expansion of firm capital since SEO may dilute the EPS or reduce the rate of return on equity. As with the pecking order theory of capital structure, the issuance of stock should be the final choice when the firm needs to raise funds, because of asymmetric information between firm managers and investors. Thus, it could be inferred that investors of ADRs might pay more attention to the change of SRs after SEOs.

The results on the TSCSREG tests of other pairs present a simpler pattern. The SR has a dominant effect over USI, DEPS, and AEPS on ADRNs after SEOs, but the difference is not so significant pre-SEO except for the comparison with AEPS. This somewhat corresponds to the observation above that the effect of SRs is important post-SEO. The effect of investor sentiment dominates that of EPS, with LD being significant pre-SEO and USI post-SEO. The influence of USI is higher than that of LD, but only in the post-SEO period. Overall, our findings indicate that SR constitutes the most important determinant of Latin American ADRNs in the two sub-periods. However, EPS has no effect on ADRNs, whether it is represented by local accounting standards or reconciled to US GAAP. Moreover, the relative importance between DEPS and AEPS cannot be distinguished as well. Finally, the effect of investor sentiment is mixed in the two subperiods.

\subsection{Asian Results}

Table 9 lists the Asian regression results both pre- and post-SEO. As shown, the problem of serial correlation is absent because the DW statistic is near 2. The robust standard error estimates are still employed because of heteroskedasticity problem. The SRs, LD, and USI exert roughly equal positive and significant influences over ADRNs during the full period, except for LD as it strongly and negatively impacts ADRNs post-SEO. The null hypotheses that the SRs, LD, and USI affect ADRNs equally during domestic stock pre- and post-SEOs cannot be rejected. DEPS and AEPS exert an insignificant effect 


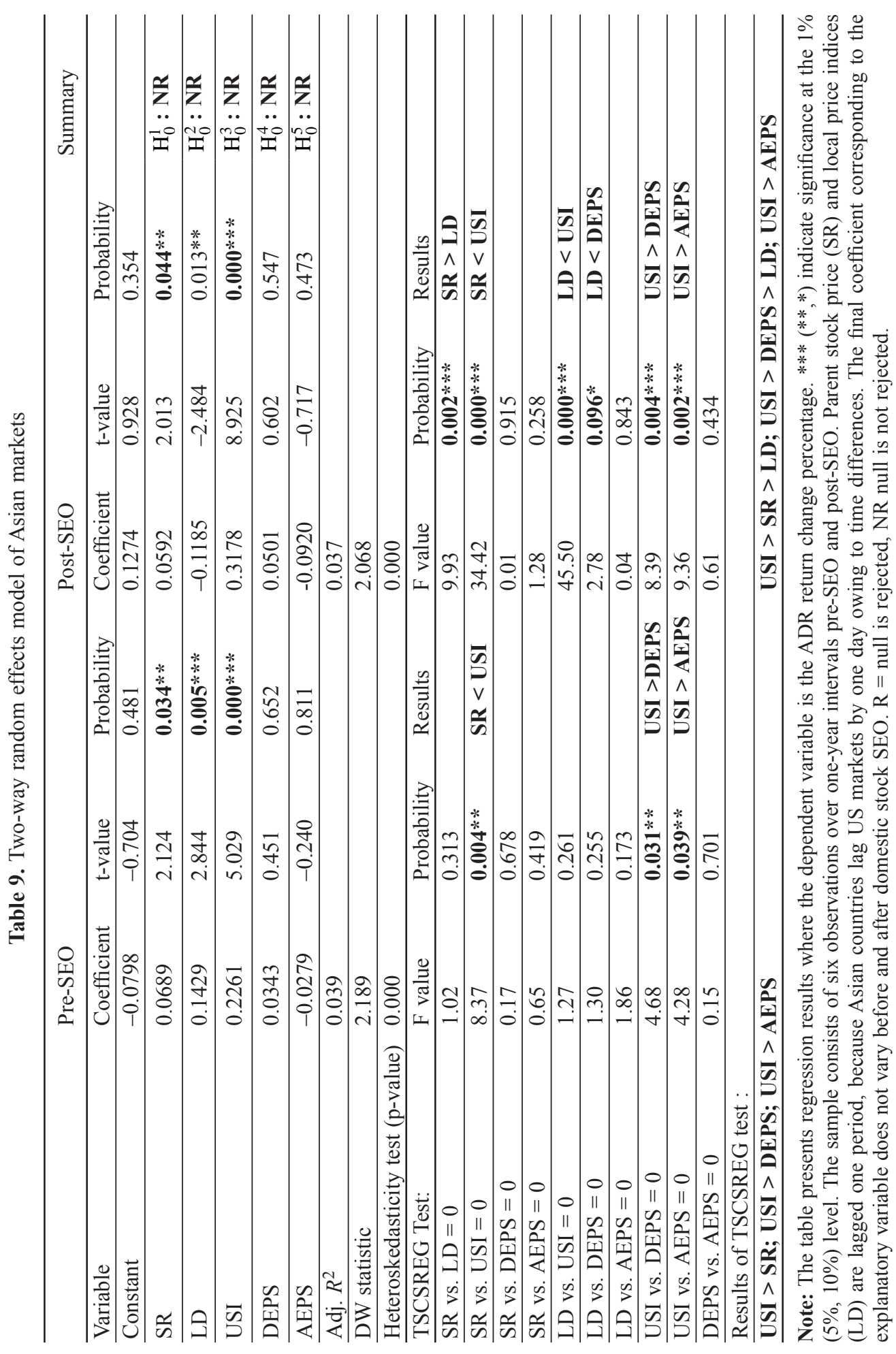


on ADRNs for the full period. Thus, the Asian sample exhibits limited informativeness of AEPS and DEPS in amplifying ADRNs, which is consistent with the findings for Latin America.

Table 9 shows the $t$-values that Asian ADRNs are most influenced by USI for the full period, and the TSCSREG tests present that USI dominates SR, DEPS, and AEPS in explaining ADRNs during the two sub-periods and dominates LD in the post-SEO period. The TSCSREG results cannot determine the relative significance either before or after domestic stock SEOs in the following pairs: SR versus DEPS, SR versus AEPS, LD versus AEPS, and DEPS versus AEPS. In sum, our findings support the view that USI is the most important determinant of Asian ADRNs in all periods.

The panel model and TSCSREG procedures above confirm that the most notable effect comes from USI for the Asia sample, while for the Latin American sample the SRs dominate. Consistent with Phylaktis and Xia (2007), Asian markets are more responsive to the US markets than to other regional markets. The TSCSREG results cannot distinguish the relative importance of DEPS versus AEPS both for the Asia and Latin American samples, which is consistent with Kirch's (2007) findings that indicate that DEPS and AEPS contain little information about ADRNs. Choi and Kim (2000) examined the determinants of ADRNs and mentioned that developed and emerging markets have divergent findings in terms of the determinants of ADRNs. Our findings indicate that even emerging markets have diverse findings in terms of the determinants of ADRNs. Ferguson (2000) stated that investor sentiment shifted more rapidly in Asia than it did in Latin America, because investors were already more familiar with the regional structural inefficiencies and difficulties in Latin America than in Asia. This article to some extent reflects Ferguson's point since our findings demonstrate that investor sentiment, either in the local or US markets, plays a more important role on ADR returns for the Asia sample than for the Latin American sample.

\subsection{Robustness Checking}

To examine the stability of previous results, we exclude insignificant variables in the initial model and perform the same analysis for the four sample groups. The results are presented in Tables 10 and 11. As can be seen from the two tables, our findings are qualitatively the same as the results above. The domestic stock return still plays a critical role both pre- and post-SEO for Latin American samples, USI dominates ADRNs over other factors for the Asia sample, and the significance of other variables is similar to the initial model. Hence, our observations are robust.

Since SR might be an endogenous variable, an instrumental variable approach should be used (Pangan, Ullah 1988). The instrumental estimation technique used in this study is the panel system GMM estimator. This technique estimates a system by combining two sets of equations. An alternative would be the first-differenced GMM procedure. However, the procedure suffers from weak instrument problems and can produce biased results - for instance, owing to heteroskedasticity problems and autoregressive parameters with values around unity (Blundell, Bond 1998). In all estimations, this study controls for time effects and firm effects by adopting random effects models. 
Table 10. Robustness checking: Two-way random effects model of Latin American markets - excluding insignificant variables in initial model

\begin{tabular}{|c|c|c|c|c|c|c|c|}
\hline & Pre-SEO & & & Post-SEC & & & Summary \\
\hline Variable & $\begin{array}{l}\text { Coeffi- } \\
\text { cient }\end{array}$ & t-value & $\begin{array}{l}\text { Proba- } \\
\text { bility }\end{array}$ & $\begin{array}{l}\text { Coeffi- } \\
\text { cient }\end{array}$ & t-value & $\begin{array}{l}\text { Proba- } \\
\text { bility }\end{array}$ & \\
\hline Constant & 0.3823 & 1.292 & 0.196 & 0.0402 & 1.044 & 0.297 & \\
\hline SR & 0.0847 & 1.878 & $0.061 *$ & 0.6429 & 21.466 & $0.000 * * *$ & $\mathrm{H}_{0}^{1}: \mathbf{N R}$ \\
\hline LD & 0.4329 & 4.164 & $0.000 * * *$ & & & & $\mathrm{H}_{0}^{2}: \mathbf{R}$ \\
\hline USI & & & & 0.3279 & 5.474 & $0.000 * * *$ & $\mathrm{H}_{0}^{3}: \mathbf{R}$ \\
\hline Adj. $R^{2}$ & 0.002 & & & 0.257 & & & \\
\hline DW statistic & 2.186 & & & 2.766 & & & \\
\hline $\begin{array}{l}\text { Heteroske- } \\
\text { dasticity test } \\
\text { (p-value) }\end{array}$ & 0.000 & & & 0.000 & & & \\
\hline TSCSREG test: & $\mathrm{F}$ value & Probability & Result & $\mathrm{F}$ value & Probability & & Result \\
\hline$\overline{S R}$ vs. $L D=0$ & 6.30 & $0.012 * *$ & SR $<$ LD & & & & \\
\hline SR vs. USI $=0$ & & & & 17.61 & $0.000 * * *$ & & SR $>$ USI \\
\hline \multicolumn{8}{|c|}{ Results of TSCSREG test: } \\
\hline LD $>$ SR & & & & SR $>$ US & & & \\
\hline
\end{tabular}

Note: See Table 8.

Table 11. Robustness checking: Two-way random effects model of Asian markets - excluding insignificant variables in initial model

\begin{tabular}{|c|c|c|c|c|c|c|c|}
\hline & Pre-SEO & & & Post-SE & & & Summary \\
\hline Variable & $\begin{array}{l}\begin{array}{l}\text { Coeffi- } \\
\text { cient }\end{array} \\
\end{array}$ & t-value & $\begin{array}{l}\text { Proba- } \\
\text { bility }\end{array}$ & $\begin{array}{l}\text { Coeffi- } \\
\text { cient }\end{array}$ & t-value & $\begin{array}{l}\text { Proba- } \\
\text { bility }\end{array}$ & \\
\hline Constant & -0.0732 & -0.976 & 0.329 & 0.1069 & 1.285 & 0.199 & \\
\hline SR & 0.0690 & 2.131 & $0.033 * *$ & 0.0600 & 2.035 & $0.042 * *$ & $\mathrm{H}_{0}^{1}: \mathbf{N R}$ \\
\hline LD & 0.1423 & 2.826 & $0.005 * * *$ & -0.1185 & -2.484 & 0.013 ** & $\mathrm{H}_{0}^{2}$ : NR \\
\hline USI & 0.2258 & 5.017 & $0.000 * * *$ & 0.3183 & 8.938 & $0.000 * * *$ & $\mathrm{H}_{0}^{3}: \mathbf{N R}$ \\
\hline Adj. $R^{2}$ & 0.040 & & & 0.038 & & & \\
\hline DW statistic & 2.189 & & & 2.067 & & & \\
\hline $\begin{array}{l}\text { Heteroske- } \\
\text { dasticity test } \\
\text { (p-value) }\end{array}$ & 0.000 & & & 0.000 & & & \\
\hline TSCSREG Test: & $\mathrm{F}$ value & Probability & Results & F value & Probability & Results & \\
\hline SR vs. $L D=0$ & 1.00 & 0.318 & & 9.96 & $\mathbf{0 . 0 0 2} * * *$ & $\mathrm{SR}>\mathrm{LD}$ & \\
\hline SR vs. USI $=0$ & 8.32 & $0.004 * *$ & SR $<$ USI & 34.29 & $0.000 * * *$ & SR $<$ USI & \\
\hline LD vs. USI $=0$ & 1.27 & 0.259 & & 45.60 & $0.000 * * *$ & LD $<$ USI & \\
\hline \multicolumn{8}{|c|}{ Results of TSCSREG test : } \\
\hline USI > SR & & & & \multicolumn{4}{|c|}{ USI $>$ SR $>$ LD } \\
\hline
\end{tabular}

Note: See Table 9. 
Table 12 lists the robustness check for panel system GMM findings. The results are approximately the same as previous empirical results for the Asian sample. The coefficients are similar to the initial results, and variables significantly affecting ADRNs remain the same. On the other hand, the results of post-SEO for the Latin American sample are qualitatively similar, except that LD becomes significant in the system GMM model. Finally, differences emerge in the pre-SEO results for the Latin American sample. SR still significantly affects ADRNs, but the effect of LD is not significant now. Sample characteristics might be the reason for this difference. As shown in Table 6, the pre-SEO Latin American sample reveals some difference in skewness and kurtosis in SR and ADRNs compared to other groups. Even so, the dominance of SR remains in the system GMM specifications. Largely, the above robustness checks produce similar empirical results.

Table 12. Robustness checking: Panel system GMM models

\begin{tabular}{lllll}
\hline Country & \multicolumn{2}{l}{ Latin America } & \multicolumn{2}{l}{ Asia } \\
\hline Variable & Pre-SEO & Post-SEO & Pre-SEO & Post-SEO \\
\hline Panel A: initial model & & & & \\
\hline Constant & 0.2916 & 0.0797 & -0.0882 & 0.1303 \\
& $(0.230)$ & $(0.068)^{*}$ & $(0.381)$ & $(0.229)$ \\
\hline SR & 0.8878 & 0.5387 & 0.1131 & 0.0741 \\
& $(0.000)^{* * *}$ & $(0.000)^{* * *}$ & $(0.000)^{* *}$ & $(0.008)^{* * *}$ \\
\hline LD & -0.1618 & 0.1668 & 0.1724 & -0.1081 \\
& $(0.473)$ & $(0.000)^{* * *}$ & $(0.000)^{* * *}$ & $(0.018)^{* *}$ \\
\hline USI & -0.1426 & 0.2961 & 0.2145 & 0.3171 \\
& $(0.488)$ & $(0.000)^{* * *}$ & $(0.000)^{* * *}$ & $(0.000)^{* * *}$ \\
\hline DEPS & 0.0489 & -0.0064 & 0.0394 & 0.0514 \\
& $(0.776)$ & $(0.821)$ & $(0.618)$ & $(0.545)$ \\
\hline AEPS & -0.2241 & -0.010 & -0.0275 & -0.0940 \\
& $(0.000)^{* * *}$ & $(0.417)$ & $(0.381)$ & $(0.418)$ \\
\hline Panel B: excluding insignificant variables in initial model & & \\
\hline Constant & 0.3259 & 0.0779 & -0.0780 & 0.1097 \\
& $(0.117)$ & $(0.051)^{*}$ & $(0.333)$ & $(0.206)$ \\
\hline SR & 0.8990 & 0.5565 & 0.1123 & 0.0744 \\
& $(0.000)^{* * *}$ & $(0.000)^{* * *}$ & $(0.000)^{* * *}$ & $(0.008)^{* * *}$ \\
\hline LD & -0.2414 & & 0.1724 & -0.1075 \\
& $(0.253)$ & & $(0.000)^{* * *}$ & $(0.018)^{* *}$ \\
\hline USI & & 0.3690 & 0.2152 & 0.3181 \\
& & $(0.000)^{* * *}$ & $(0.000)^{* * *}$ & $(0.000)^{* * *}$ \\
\hline No* ( & & &
\end{tabular}

Note: ( ): p-value. ${ }^{* * *}(* *, *)$ indicate significance at the $1 \%(5 \%, 10 \%)$ level. 


\section{Conclusions}

What drives the returns of ADR? This paper initially studies the issue of impact changes regarding accounting/investor sentiment and local/US variables on ADRNs by controlling the information transmission of domestic stock SEOs for ADRs in Latin American and Asian emerging markets from 1990 to 2007. We empirically contrast the longrun determinants of ADRNs both before and after domestic stock SEOs and contrast Latin America with Asia emerging economies. By following the model of Chan and Seow (1996) and Grossmann et al. (2007), we apply the two-way random effects panel data models and TSCSREG to investigate the changing influence of relative factors on ADRNs. Finally, panel system GMM models are also employed in the robustness check. This study incrementally contributes to the behavioral finance and accounting literature by providing evidence of the informativness of investor sentiment and ADR-reconciled accounting information.

This paper demonstrates the following empirical results. First, the estimated coefficient on the SR is positively and statistically significant in Latin American pre- and postSEO models. The estimated coefficient on the SR in Table 8, for example, is 0.6. This means that a one unit increase in SR after domestic stock SEO increases ADRNs by $0.6 \%$ over a 1-year period. The relationship between SRs and Latin American ADRNs is consistent with 'law of one price'. However, USI positively dominates in the Asian sample, indicating one unit increase in USI increases Asian ADRN by 0.2 to $0.3 \%$ over a 1 -year period before and after domestic stock SEO, respectively. Remarkably, LD even dominates SR in explaining Asian ADRNs. The results provide similar evidence with Ferguson (2000) in that investor sentiment shifted more rapidly in Asia than it did in Latin America, because investors were already more familiar with the regional structural inefficiencies and difficulties in Latin America than in Asia. Consistent with Grossmann et al. (2007) and Kirch (2007), this study ascertains that the USI has a leading relationship among equity markets, and AEPS and DEPS convey little information regarding ADRNs. However, our study expands the research sample into the Latin American/ Asian emerging markets and makes before and after domestic stock SEO comparisons. The TSCSREG results also permit us to conclude that SR is more important than USI for Latin American ADRNs, with the reverse holding true in Asia.

Second, regarding the difference between pre- and post-SEOs, TSCSREG and twoway random effects models specify that USI (LD) considerably affects Latin American ADRNs post (pre)- but not pre (post)-SEO. The sole difference between the pre- and post-SEOs based on the Asian market is that SRs dominate LD in explaining ADRNs post-SEO, but this state is not significant pre-SEO. Moreover, SRs, LD, and USI exert significant influences on ADRNs during the full period for the Asian sample. Both of Latin American and Asian markets' results cannot pinpoint the comparative significance of DEPS versus AEPS. However, Latin American and Asian findings identify USI presents more salient influence than LD post-SEO. Although classic finance theory does not acknowledge behavioral factors as market sentiment, the empirical findings imply that asset prices are affected by the place they are traded (Suh 2003), especially confirmed in Asian ADRs of the research. We offer that ADRs from Latin America and 
Asia emerging markets have distinct and similar features that need to be noticed when planning investment strategies. Also, our findings suggest that ADRs provide diversification benefits through two different sources: a market of origin diversification, and a specific feature of domestic stock diversification.

Finally, the estimated coefficients on the DEPS and AEPS variables for both Latin American and Asian ADRNs are statistically insignificant at conventional levels, indicating that changes in DEPS and AEPS have little impact on ADRNs from Latin American and Asian emerging markets, whether pre- or post-SEO. This finding may result from the distinctly important influence of annual accounting information versus daily investor sentiment data. Our finding is different from both Pope and Rees (1992) and Chan and Seow (1996), showing that DEPS dominates AEPS, or from Luchs (2004), indicating that DEPS has the same importance as AEPS. Their results may be mainly caused by no information transmission considerations and/or no comparison with other factors in the previous literature. Thus, we support the cost reduction view of accounting convergence and not that of a reduction in asymmetrical information.

\section{Acknowledgments}

We would like to thank the editor and two anonymous referees for their valuable comments and suggestions which have gone a far way in helping us to improve the quality of our paper. All errors and omissions remain our responsibility.

\section{References}

Alaganar, V. T.; Bhar, R. 2001. Diversification gains from American depository receipts and foreign equities: Evidence from Australian stocks, Journal of International Financial Markets, Institutions and Money 11(1): 97-113. doi:10.1016/S1042-4431(00)00038-X

Alexander, G. J.; Eun, C. S.; Janakiramanan, S. 1988. International listings and stock returns: Some empirical evidence, Journal of Financial and Quantitative Analysis 23(2): 135-151. doi: $10.2307 / 2330877$

Amir, E.; Harris, T. S.; Venuti, E. K. 1993. A comparison of the value-relevance of US versus Non-US GAAP accounting measures using Form 20-F reconciliations, Journal of Accounting Research 31: 230-264. doi:10.1016/j.intacc.2004.08.001

Aquino, K. P.; Poshakwale, S. 2006. Price determinants of ADR: A cross-sectional analysis of panel data, Applied Financial Economics 16(16): 1225-1237. doi:10.1080/09603100500447503

Areal, F. J.; Ceddia, M. G.; Pazienza, P. 2007. Predicting the impact of the EU common agricultural policy reform in England: Micro and macroeconomic aspects, Journal of Business Economics and Management 8(4): 237-244.

Arellano, M. 2003. Panel Data Econometrics. New York: Oxford University Press. doi:10.1093/0199245282.003.0001

Arquette, G. C.; Brown, W. O.; Burdekin, R. C. 2008. US ADR and Hong Kong H-share discounts of Shanghai-listed firms, Journal of Banking and Finance 32(9): 1916-1927.

doi:10.1016/j.jbankfin.2007.12.019

Bae, S. C.; Kwon, T. H.; Li, M. 2008. Foreign exchange rate exposure and risk premium in international investments: Evidence from American depository receipts, Journal of Multinational Financial Management 18(2): 165-179. doi:10.1016/j.mulfin.2007.07.001

Bailey, W.; Stulz, R. M. 1990. Benefits of international diversification: The case of Pacific Basin stock markets, Journal of Portfolio Management 16(4): 57-61. doi:10.3905/jpm.1990.409287 
Barberis, N.; Shleifer, A.; Wurgler, J. 2005. Comovement, Journal of Financial Economics 75(2): 283-317. doi:10.1016/j.jfineco.2004.04.003

Baumol, W. J.; Malkiel, B. G. 1993. Redundant regulation of foreign security trading and US competitiveness, Journal of Applied Corporate Finance 5(4): 19-27.

doi:10.1111/j.1745-6622.1993.tb00358.x

Black, F. 1986. Noise, Journal of Finance 41(3): 529-543. doi:10.2307/2328481

Blundell, R.; Bond, S. 1998. Initial conditions and moment restrictions in dynamic panel data models, Journal of Econometrics 87(1): 115-143. doi:10.1016/S0304-4076(98)00009-8

Bradshaw, M. T.; Bushee, B. J.; Miller, G. S. 2004. Accounting choice, home bias, and US investment in Non-US Firms, Journal of Accounting Research 42(5): 795-841.

doi:10.1111/j.1475-679X.2004.00157.x

Brooks, C. 2002. Introductory Econometrics for Finance. $1^{\text {st }}$ ed. Cambridge University Press: Cambridge, United Kingdom. 163 p.

Callaghan, J. H.; Kleiman, R. T.; Sahu, A. P. 1999. The market-adjusted investment performance of ADR IPOs and SEOs, Global Finance Journal 10(2): 123-145.

doi:10.1016/S1044-0283(99)00014-9

Chan, K. C.; Seow, G. S. 1996. The association between stock returns and foreign GAAP earnings versus earning adjusted to US GAAP, Journal of Accounting and Economics 21(1): 139-158. doi:10.1016/0165-4101(95)00405-X

Cheng, Y. H.; Kuan, F. Y.; Chuang. S. C. 2010. Profitability decided by patent quality? An empirical study of the US semiconductor industry, Scientometrics 82: 175-183.

doi:10.1007/s11192-009-0080-4

Choi, Y. K.; Kim, D. S. 2000. Determinants of American depository receipts and their underlying stock returns: Implications for international diversification, International Review of Financial Analysis 9(4): 351-368. doi:10.1016/S1057-5219(00)00041-7

Coakley, J.; Kougoulis, P. 2004. Comovement and changes to the FTSE 100 Index, Working paper. University of Essex, Essex Finance Centre Discussion Paper no. Available from Internet: $<$ http://ssrn.com/abstract=493003>.

DeLong, J. B.; Shleifer, A.; Summers, L. H.; Waldman, R. J. 1990. Noise trader risk in financial markets, Journal of Political Economy 98(4): 703-738.

Denis, D. J.; Sarin, A. 2001. Is the market surprised by poor earnings realizations following seasoned equity offerings?, Journal of Financial and Quantitative Analysis 36(2): 169-193. doi: $10.2307 / 2676270$

D’Mello, R.; Tawatnuntachai, O.; Yaman, D. 2003. Does the sequence of seasoned equity offerings matter? Financial Management 32(4): 59-86. doi:10.2307/3666136

Ehrmann, M.; Fratzscher, M. 2005. Equal size, equal role? Interest rate interdependence between the Euro Area and the United States, Economic Journal 115(506): 928-948.

doi:10.1111/j.1468-0297.2005.01025.x

Ejara, D. D.; Ghosh, C. 2004. Underpricing and aftermarket performance of American depository receipts IPOs, Journal of Banking and Finance 28(12): 3151-3186.

doi:10.1016/j.jbankfin.2004.05.006

Ely, D.; Salehizadeh, M. 2001. American Depository Receipts: An analysis of international stock price movements, International Review of Financial Analysis 10(4): 343-363.

doi:10.1016/S1057-5219(01)00058-8

Ferguson, R. W. 2000. Tale of two continents: A comparison of Asian and Latin American experiences during recent financial turmoil. Available from Internet: <http://www.federalreserve.gov/ boarddocs/speeches/2000/20000107.htm>. 
Foerster, S. R.; Karolyi, G. A. 1999. The effects of market segmentation and investor recognition on asset prices: Evidence from Foreign Stock Listings in the United States, Journal of Finance 54(3): 981-1013. doi:10.1111/0022-1082.00134

Foerster, S. R.; Karolyi, G. A. 2000. The long run performance of global equity offerings, Journal of Financial and Quantitative Analysis 35: 499-528. doi:10.2307/2676253

Froot, K. A.; Dabora, E. M. 1999. How are stock prices affected by the location of trade?, Journal of Financial Economics 53(2): 189-216. doi:10.1016/S0304-405X(99)00020-3

Gombola, M.; Lee, H. W.; Liu, F. Y. 1997. Evidence of selling by managers after seasoned equity offering announcements, Financial Management 26(3): 37-53. doi:10.2307/3666212

Gombola, M.; Lee, H. W.; Liu, F. Y. 1999. Further evidence on insider selling prior to seasoned equity offering announcements: The role of growth opportunities, Journal of Business Finance and Accounting 26: 621-649. doi:10.1111/1468-5957.00269

Grossmann, A.; Ozuna, T.; Simpson, M. W. 2007. ADR mispricing: Do costly arbitrage and consumer sentiment explain the price deviation? Journal of International Financial Markets, Institutions and Money 17(4): 361-371. doi:10.1016/j.intfin.2006.02.001

Gujarati, D. N. 2003. Basic Econometrics (4th ed.). New York: McGraw-Hill/Irwin.

Hausman, J. A. 1978. Specification tests in econometrics, Econometrica 46(6): 1251-1271.

doi: $10.2307 / 1913827$

Jackson, D.; Madura, J. 2003. Profit warnings and the pricing behavior of ADRs, Journal of Behavioral Finance 4(3): 131-136. doi:10.1207/S15427579JPFM0403_3

Jayakumar, V. 2002. Impact of international cross-listing on local exchanges: Evidence from Chile, International Review of Finance 3: 189-211. doi:10.1111/j.1369-412X.2002.00038.x

Jiang, C. X. 1998. Diversification with American depository receipts: The dynamics and the pricing factors, Journal of Business Finance and Accounting 25: 683-699.

doi:10.1111/1468-5957.00207

Karolyi, G. A. 2004. The Role Of American depository receipts in the development of emerging equity Markets, Review of Economics and Statistics 86(3): 670-690. doi:10.1162/0034653041811699

Kato, K.; Linn, S.; Schallheim, J. 1991. Are there arbitrage opportunities in the market for American depository receipts?, Journal of International Financial Markets, Institutions and Money 1: 73-89.

Kim, M.; Szakmary, A.; Mathur, I. 2000. Price transmission dynamics between ADRs and their underlying foreign securities, Journal Banking and Finance 24(8): 1359-1382.

doi:10.1016/S0378-4266(99)00076-X

Kirch, G. 2007. Mind the GAAP? Market reaction to accounting principles: Evidence from Brazilian cross-listed stocks, International Journal of Business Research 7(3): 217-227.

Lee, H. W. 1997. Post offering earnings performance of firms that issue seasoned equity: The Role of Growth Opportunities, Quarterly Review of Economics and Finance 37(1): 97-114. doi:10.1016/S1062-9769(97)90060-0

Luchs, C. 2004. The relations of financial accounting systems and country risk: An examination of ADRs, Journal of Accounting and Finance Research 12(6): 59-69.

MacDonald, S. 2005. Emerging markets - Is this as good as it gets? Available from Internet: $<$ www.safehaven.com/article-2681.htm>.

Mak, B. S.; Ngai, A. M. 2005. Market linkage for dual-listed Chinese stocks, The Chinese Economy 38(2): 88-107.

Maldonado, R.; Saunders, A. 1983. Foreign exchange restrictions and the law of one price, $F i$ nancial Management 12(1): 19-23. doi:10.2307/3664833

Meek, G. K. 1983. US Securities market's responses to alternative earnings disclosures of NonUS multinational corporations, Accounting Review 58(2): 394-402.

Meek, G. K.; Saudagaran, S. M. 1990. A survey of research on financial reporting in a transnational context, Journal of Accounting Literature 9: 145-182. 
Miller, D. P. 1999. The market reaction to international cross-listings: Evidence from depository receipts, Journal of Financial Economics 51(1): 103-123. doi:10.1016/S0304-405X(98)00045-2 Minana, L. E. 2003. Weekly comment on Puerto Rico stocks, Caribbean Business 31: 12-14.

Mola, S.; Loughran, T. 2004. Discounting and clustering in seasoned equity offering prices, Journal of Financial and Quantitative Analysis 39(1): 1-23. doi:10.1017/S0022109000003860

Montier, J. 2002. Behavioural Finance: Insight into Irrational Minds and Markets. John Wiley \& Sons Ltd. 169 p.

Moulton, B. R. 1986. Random group effects and the precision of regression estimates, Journal of Econometrics 32(3): 385-397. doi:10.1016/0304-4076(86)90021-7

Nielsen, F. 1999. Analysis of pooled time series of cross sections, Odum Institute 45 (March): 76-94.

Officer, D. T.; Hoffmeister, J. R. 1987. ADRs: A substitute for the real thing?, Journal of Portfolio Management 13(2): 61-65. doi:10.3905/jpm.1987.61

Pangan, A.; Ullah, A. 1988. The econometric analysis of models with risk terms, Journal of Applied Econometrics 3(2): 87-105. doi:10.2307/135443

Park, J.; Tavakkol, A. 1994. Are ADRs a dollar translation of their underlying securities?: The Case of Japanese ADRs, Journal of International Financial Markets, Institutions and Money 4(1): 77-87.

Patro, D. K. 2000. Return behavior and pricing of American depository receipts, Journal of International Financial Markets, Institutions and Money 10(1): 43-67.

Phylaktis, K.; Xia, L. 2007. Equity market comovement and contagion: A sectorial perspective. EMG Working Paper Series no.WP-EMG-01-2007.

Pope, P. F.; Rees, W. P. 1992. International differences in GAAP and the pricing of earnings, Journal of International Financial Management and Accounting 4(3): 190-219. doi:10.1111/j.1467-646X.1992.tb00029.x

Santiago-Castro, M.; Brown, M. C. 2007. Ownership structure and minority rights: A Latin American view, Journal of Economics and Business 59: 430-442. doi:10.1016/j.jeconbus.2007.04.005

Siegel, J. J. 1998. Stocks for the Long Run: the definitive guide to financial market returns and long-term investment strategies. $2^{\text {nd }}$. New York: McGraw-Hill. 89 p.

Smith, C. J. 1977. Alternative methods of raising capital: Rights versus underwritten offerings, Journal of Financial Economics 5(3): 273-307. doi:10.1016/0304-405X(77)90040-X

Spiess, D. K.; Affleck-Graves, J. 1995. Underperformance in long-run stock returns following seasoned equity offerings, Journal of Financial Economics 38(3): 243-267.

doi:10.1016/0304-405X(94)00817-K

Suh, J. 2003. ADRs and US market sentiment, Journal of Investing 12(4): 87-95.

doi:10.3905/joi.2003.319572

Sundaram, A. K.; Logue, D. E. 1996. Valuation effects of foreign company listings on US exchanges, Journal of International Business Studies 27(1): 67-88.

doi:10.1057/palgrave.jibs.8490127

Wahab, M.; Lashgari, M.; Cohn, R. 1992. Arbitrage opportunities in the American depository receipts market revisited, Journal of International Financial Markets, Institutions and Money 2: 97-130.

Wang, C. Y. 2003. Investor sentiment, market timing, and futures returns, Applied Financial Economics 13(12): 871-878. doi:10.1080/0960310032000129653

Webb, S. E.; Officer, D. T.; Boyd, B. E. 1995. An examination of international equity markets using ADRs, Journal of Business Finance and Accounting 22(3): 415-430.

doi:10.1111/j.1468-5957.1995.tb00882.x 
C.-C. Lee et al. Determinants of ADR returns before and after domestic stock seasoned equity offerings ...

\section{APPENDIX}

ADR summary of sample firms

\begin{tabular}{|c|c|c|c|c|c|}
\hline No. & DR issue & Exchange & Country & Industry & $\begin{array}{l}\text { Effective } \\
\text { date }\end{array}$ \\
\hline 1 & $\begin{array}{l}\text { COMPANHIA } \\
\text { SIDERURGICA NACIONAL }\end{array}$ & NYSE & Brazil & Manufacturing & 3 Nov 97 \\
\hline 2 & EMBRAER & NYSE & Brazil & Manufacturing & $26 \mathrm{Jul} 00$ \\
\hline 3 & $\begin{array}{l}\text { NET SERVICOS DE } \\
\text { COMUNICACAO }\end{array}$ & NASDAQ & Brazil & Media & 17 Dec 01 \\
\hline 4 & $\begin{array}{l}\text { PETROLEO BRASILEIRO } \\
\text { S.A.- COMMON }\end{array}$ & NYSE & Brazil & $\begin{array}{l}\text { Oil \& Gas } \\
\text { Producers }\end{array}$ & 9 Aug 00 \\
\hline 5 & SABESP & NYSE & Brazil & Water Supply & 9 May 02 \\
\hline 6 & $\begin{array}{l}\text { UNIBANCO - UNIAO DE } \\
\text { BANCOS BRASILEIROS }\end{array}$ & NYSE & Brazil & Banks & 27 Mar 01 \\
\hline 7 & AFP PROVIDA S.A. & NYSE & Chile & General Finance & 16 Nov 94 \\
\hline 8 & $\begin{array}{l}\text { COMPANIA DE } \\
\text { TELECOMUNICACIONES }\end{array}$ & NYSE & Chile & Fixed Line Telecom. & 1 Jan 97 \\
\hline 9 & ENERSIS S.A. & NYSE & Chile & Electricity & 26 Oct 93 \\
\hline 10 & MADECO S.A. & NYSE & Chile & Manufacturing & 28 May 93 \\
\hline 11 & LAN AIRLINES SA & NYSE & Chile & Transportation & 25 Mar 03 \\
\hline 12 & $\begin{array}{l}\text { SOC. QUIMICA Y MINERA } \\
\text { DE CHILE, S.A. }\end{array}$ & NYSE & Chile & Manufacturing & 1 Sep 93 \\
\hline 13 & $\begin{array}{l}\text { ENDESA-EMPRESA } \\
\text { NACIONAL DE } \\
\text { ELECTRICIDAD }\end{array}$ & NYSE & Chile & Electricity & $12 \mathrm{Jul} 94$ \\
\hline 14 & CEMEX S.A. DE CV & NYSE & Mexico & Manufacturing & 1 Sep 99 \\
\hline 15 & $\begin{array}{l}\text { DESARROLLADORA } \\
\text { HOMEX }\end{array}$ & NYSE & Mexico & Construction & 29-Jun-04 \\
\hline 16 & $\begin{array}{l}\text { EMPRESAS ICA, S.A. } \\
\text { DE C.V. }\end{array}$ & NYSE & Mexico & Construction & 1 Apr 92 \\
\hline 17 & $\begin{array}{l}\text { GRUPO SIMEC SAB DE } \\
\text { CV }\end{array}$ & NYSE & Mexico & Manufacturing & 30 Jun 93 \\
\hline 18 & PT INDOSAT TBK & NYSE & Indonesia & Mobile Telecom. & 1 Oct 94 \\
\hline 19 & $\begin{array}{l}\text { PT TELEKOMUNIKASI } \\
\text { INDONESIA TBK }\end{array}$ & NYSE & Indonesia & Fixed Line Telecom. & 21 Nov 95 \\
\hline 20 & KT CORPORATION & NYSE & S. Korea & Fixed Line Telecom. & 26 May 99 \\
\hline 21 & HANARO TELECOM INC. & NASDAQ & S. Korea & Fixed Line Telecom. & 30 Mar 00 \\
\hline 22 & SK TELECOM & NYSE & S. Korea & Mobile Telecom. & 2 Jul 96 \\
\hline 23 & $\begin{array}{l}\text { MACRONIX } \\
\text { INTERNATIONAL } \\
\text { COMPANY LIMITED }\end{array}$ & NASDAQ & Taiwan & $\begin{array}{l}\text { Technology } \\
\text { Hardware \& } \\
\text { Equipment }\end{array}$ & 9 May 96 \\
\hline
\end{tabular}

Note: See Table 2. 


\title{
DEPOZITORINIŲ PAKVITAVIMU PASISKIRSTYMAS: AZIJOS IR LOTYNŲ AMERIKOS RINKOSE
}

\author{
C.-C. Lee, M.-P. Chen, C.-A. Li, C.-H. Chang
}

\section{Santrauka}

Nagrinejjami pagrindiniai Amerikos depozitoriumo pakvitavimu (ADR) grąžinimai, apimantys 19902007 metų laikotarpi. Straipsnio autoriai tai traktuoja kaip iki šiol netirtą reiškini, nes analizuojamos dvi skirtingos rinkos - Azijos ir Lotynu Amerikos. Pasirinktu periodu šiose rinkose buvo jaučiamas ekonominis pakilimas. Straipsnio autoriai taiko laiko eilutès regresijos ir bendraji fiksuoto momento metodą. Tyrimo rezultatai parode, kad yra tam tikrų skirtumų ne tik tarp regionų, bet ir tarp atskirų investuotojų bei jų susiformavusių požiūrių i šias rinkas. Pažymima, kad turi būti ịvertinami tiek rinkos, tiek geografiniai skirtumai difersifikuojant investicijas.

Reikšminiai žodžiai: Amerikos depozitoriumo pakvitavimai, apskaitos informacija, investicijos, investuotoju požiūriai.

Chien-Chiang LEE. Associate Professor of Department of Finance at National Sun Yat-sen University. His research areas include banking and finance. He is an Associate Editor of Energy Economics and has recent publications in Journal of Money, Credit and Banking, Journal of Financial Services Research, Urban Studies, Scottish Journal of Political Economy, Empirical Economics, Energy Economics, and Energy Journal.

Mei-Ping CHEN. Associate Professor of Accounting Information at National Taichung Institute of Technology, got her PhD in Management at the National Yunlin University of Science \& Technology. Her research work has appeared in the International Research Journal of Finance and Economics, International Journal of Management, International Journal of Business and Strategy, and Economic Modelling. Research interests are capital markets, financial management, financial accounting, and behavioral finance.

Chun-An LI. Professor and Dean of the College of Finance and Banking, National Kaohsiung First University of Science and Technology. He received his $\mathrm{PhD}$ from National Chengchi University. His research areas include corporate governance, asset pricing, asset allocation, behavioral finance. His research papers have been published in Journal of Management, Review of Securities and Future Markets, Management Review, Journal of Financial Studies, Taiwan Economic Review, Journal of Management \& System, and Taiwan Academy of Management Journal.

Chi-Hung CHANG. PhD candidate of Department of Finance at National Sun Yat-sen University. His research interests are the development in financial and insurance markets. 